\title{
Oral health care after the National Policy on Oral Health - "Smiling Brazil": a case study
}

\footnotetext{
Aline Guerra Aquilante ${ }^{1}$ Geovani Gurgel Aciole ${ }^{1}$
}

\footnotetext{
${ }^{1}$ Programa de PósGraduação em Saúde Coletiva, Departamento de Medicina, Universidade Federal de São Paulo. R. Botucatu $740 / 4^{\circ}$ andar, Vila Clementino. 04023-900 São Paulo SP Brasil. aline@ufscar.br
}

\begin{abstract}
In 2004, the National Oral Health Policy (PNSB) - Smiling Brazil was launched. Its guidelines seek to qualify Primary Health Care, ensure comprehensive actions, work on the basis of health surveillance, plan actions in accordance with the epidemiology and information available on the territory, financing and scheduling the research agenda so that the work can be based on scientific evidence. The purpose of this case study was to investigate the perspectives of health care professionals and managers on oral health care after launching the PNSB. For the gathering of information, an oral interview was conducted with health care professionals and managers and direct observation of oral health services. The interpretation of meaning method was used for analysis of the interviews. Approximately 10 years after launching the PNSB, even though the care and the oral health actions have been amplified and qualified, the cities still find it difficult to implement their basic premises.

Key words Oral health, Health policy, Research into health services, Evaluation of health projects and programs
\end{abstract}




\section{Introduction}

The Brazilian public oral health care system, which is focused on curative/mutilating ${ }^{1}$ treatment, was modelled on the 'Incremental System' that was imported from the USA through the SESP Foundation in the 1950s. This approach focuses on the treatment needs of a defined population, including full treatment. In Brazil, clinical care and fluoride application for school children up to the age of 14 was prioritized because this was the group that was most vulnerable, most sensitive to public health interventions, and easiest to reach because it was concentrated in the school environment ${ }^{2-6}$. Adults and the elderly were offered emergency dental procedures.

The SUS (National Health Service) attempted to break this SESP-based model. However, there was only very limited success in expanding access, developing promotion and prevention policies, and offering more complex treatments ${ }^{1,2,7}$. In 2004, the National Oral Health Policy (PNSB), 'Smiling Brazil', was launched, which sought to incorporate principles of universal and comprehensive treatment, and which was intended to do the following: refocus assistance by promoting health as an axis of care; provide universal access to services by inserting oral health in the lines of care; and to consider all levels of care (integrality) by installing DSCs (dental specialty centers) and regional laboratories of prosthodontics. Public service oral health care was no longer restricted to primary care for school children and pregnant women ${ }^{4,8,9}$ because the PNSB expanded access to services, mainly through including oral health teams in the Family Health Strategy and by the opening of DSCs ${ }^{7,8,10-14}$.

A decade later, the challenge that still remains is to build a consistent oral health care policy with the principles of the SUS. In this context, this study investigates treatment conditions in municipalities within the Regional Health Department of São Paulo (RHD III) after the launch of the PNSB.

\section{Methodological approach}

A case study approach was chosen because it was felt that this was an appropriate strategy to understand the 'how' and 'why' of a situation or episode, over which the evaluator had little control, and to highlight connections between interventions and real-life situations and the context in which interventions occurred, demonstrating their trajectories and how to modify them ${ }^{15}$. This was the case in relation to the PNSB in the cities that were studied.

Given the human tendency to form opinions and attitudes within the collective of which one is a part, in order to describe and analyze the contexts, relationships and perceptions of individuals concerning the PNSB, and in order to assess the understanding of references and relevant structures, interviews with semi-structured scripts were used ${ }^{16,17}$, which were complemented with focus groups ${ }^{15}$. In order to provide insights into the everyday practices and organization of services and actions, we conducted participant observation of the physical and relational environments, which is important in characterizing contexts to be studied ${ }^{15,16}$.

\section{Fieldwork}

The project was approved by the Research Ethics Committee of the Federal University of São Paulo and was presented to the local health managers of the 24 municipalities and the Board of the RHD III. After the quantitative analysis of a questionnaire, which was previously sent to the coordinators for oral health of the 24 municipalities by convenience sampling ${ }^{15}$, six municipalities were chosen that showed the best contexts of implementation of the PNSB. The following were interviewed: RHD oral health managers (2); municipal oral health managers (9); dental surgeons (23); and oral health assistants and technicians (23). Focus groups were held in four municipalities and the following participated: 28 oral health professionals; 15 dentists; and 13 oral health assistants and technicians. Participant observation was carried out where the interviews and focus groups took place.

\section{Analysis of information}

The collected material was organized according to the manner in which it was obtained (interview, focus group and participant observation) after the individual interviews and focus groups were recorded. The anonymity of respondents was ensured by using alpha-numerical coding according to profession or occupation in the following manner: SM - state manager; MM - municipal manager; DS - dental surgeons; OHT - oral health technician; OHA - oral health assistants. The type of information was coded as follows: I - interview; FG - focus group, with a randomly assigned number for the interviewee 
or focus group and fictitious names used for the municipalities (Açaí, Banana, Fig, Jambo, Orange and Mango).

The analysis considered the modes of collection (interviews, focus groups and participant observation) and the following stages of the method of interpretation of senses ${ }^{18}$ : description (to preserve the information given by the individuals participating in the study as accurately as possible); analysis (to identify the explicit and implicit categories of the information collected); and interpretation (to establish the meanings of the words and actions for understanding or explanation beyond the limits of what is described and analyzed). The information that was obtained through interviews, focus groups and participant observation was analyzed in the aforementioned manner in an attempt to seek a deeper understanding of the process of policy implementation. Seven analysis dimensions were used to categorize the results of this study: comprehensive care; interdisciplinarity; comprehensiveness of the health system; intersectorality; reception, linkage and accountability; humanization; and health surveillance.

\section{Results and discussion}

\section{Comprehensive care}

Comprehensive care, defined as the joint actions of health promotion, prevention and treatment in individual and collective areas ${ }^{19}$ implies a paradigmatic shift in professional oral health practices, which have been historically based on individual clinical care. The continuation of centralization in clinical practices is justified by pent-up demand in the area of oral health ${ }^{11,20,21}$.

The breakthrough came by looking at health in a totally different way. Before, we were just concerned about illness, and now the model is completely different, now we look at health. (MM8_ Mango)

Most units assist the patient in emergencies; there is no sequence in patient treatment. Even though the patient does not come here for their first consultation the follow-up is done here and the whole preservation treatment, until there is a review of all the treatment that was done. So, I think the bad part is the curative aspect because here we focus a lot on the curative aspect and not on the preventive aspect. (DS9_Orange)

A similar situation has been described in other studies ${ }^{11,21-25}$, which identified dental surgeons
(DSs) as being restricted to basic outpatient clinical care (extractions, plaque disclosure, dietary guidance, topical application of fluoride, restorations, oral hygiene care and basic periodontic procedures), and oral health assistants (OHAs) as being centred on conventional activities (providing instruments for DSs, disinfection and sterilization of instruments and materials), without prioritizing collective actions (home visits, prevention and health promotion, and conducting community outreach meetings). The current situation reinforces the need for professionals with a wider vision of the health/disease process who can find a balance between prevention and cure, performing actions such as participating in identifying the problems of population groups within their geographical area of responsibility for health care, and performing in multidisciplinary and interdisciplinary teams ${ }^{26}$.

However, this desired paradigm shift will not occur simply through the implementation of oral health teams. The reproduction of the biomedical model was also observed in the Family Health Units (FHUs) in the RHD III, indicating that this practice seems to be more linked to the profile of training of professionals than the type of service to which they provide. There are structural features within the dental profession that confer specific characteristics to oral health and which hinder their practice in the public sector, such as the need for the use of hard technologies (equipment $)^{23}$. This structural dependence on hard technologies (equipment) reinforces resistance to changes in the biomedical model, which is strongly supported by universities and the dental equipment and supplies industry, as well as the social imaginary of dental surgeons as professionals working in private practice. It is necessary to debate the practice of oral health in order to arrive at a model that provides a more-embracing service ${ }^{27}$ so that the wider population, which is accustomed to the procedures of the health services, can be covered by public health policies that enhance the promotion of health ${ }^{28}$.

\section{Interdisciplinarity}

Interdisciplinarity is an approach that seeks to provide a wider approach to the health/disease process through interaction between professionals from different fields of knowledge. Teamwork can achieve a positive impact on the factors involved in the health/disease process. Given the complexity of the issue of health, interdisciplinarity offers the means to preserve a measure of 
humanity in the face of technical/scientific rationality ${ }^{29-32}$.

However, changes in labour relations happen at a slow pace because the social roles of health professionals have been constructed over a long period.

Although the mutilation component is tending to become less evident ${ }^{33}$, dental surgeons come from a predominantly curative practice, while doctors are legitimized as central and dominant figures in the health services, which make labour relations both hierarchical and vertical ${ }^{34}$.

Naturally, differences were identified regarding interpersonal relationships resulting from working in teams.

The work here is very good, it's enjoyable, we work with pleasure. The team interacts; we talk a lot, so it's great to work here. (DS2_Açaí)

What are missing here are professional relationships, meetings. [...] There isn't that human warmth you need for a job to be done well, so that you might be able to develop your work. [...] There is no team here, only individuals. (DS5_Fig)

Araújo $^{35}$ also identified difficulties related to teamwork, and hierarchy is a factor that compromises comprehensive care. Despite the difficulties, there have been advances in RHD III, especially in the FHUs, where there are regular meetings and structured health education groups.

These weekly meetings we have. [...] We get together, sort out things and look at situations, everything that we see in relation to certain patients we discuss. Very often you find out how the team can help in this or that situation. [...] Yes, [we discuss aspects of the relationship between the professionals in the team], but it is not very open, it is not very open, no. (DS16_Banana)

The meetings end up being only focused only on the [community health] agent and nursing, which are the biggest problems, so there's not much to discuss in relation to the dentist in the meetings, [...] 99\% of the meetings are concerned with them, so sometimes we didn't even attend the meetings. Now we have begun to participate more often in meetings - so as not to let the service down. (DS8_ Jambo)

Because the work of DSs rarely intersects with the practices of professionals in other areas they develop their actions autonomously, independently and individually ${ }^{36}$ and what occurs in many cases is that the oral health teams (OHTs) remain as an appendix to the family health teams, which can be attributed to the late introduction of the OHT's into the Family Health Strategy $y^{11,21,24}$.
Interdisciplinary work does not represent a negation of disciplinary bases; it seeks solutions for problems that are shared by people and institutions. An interdisciplinary approach can suggest focusing on a smaller section of a wider field of knowledge. However, these smaller sections should always be viewed as such, and cannot replace the larger whole $\mathrm{e}^{30,37-40}$. Workers from different areas tend to distance themselves from things they consider to be outside their area of expertise, so as not to leave their 'comfort zone', and this can transform the field of healthcare into a space of individualism and fragmented therapeutic actions. Despite sharing the same workspaces, practices remain focused on the core knowledge of each worker without the sharing of knowledge ${ }^{27}$ because proposals focused on a collective approach still represent a challenge within the field of dentistry because training in the field is orientated towards the individual, and also because only a small part of investment in science and technology is used to address the oral health problems of relevance to public healt $h^{41}$.

The secret of interdisciplinarity lies in the successful competence of each professional, who should also be aware of their conceptual, methodological and technical limits. This awareness causes them to seek interaction with other professionals ${ }^{31}$.

\section{Comprehensiveness of the health system}

The comprehensiveness of a health system is related to the articulation of different levels of care (basic/primary, specialist/secondary, and hospital/tertiary) in order to allow service users to transit through the system so that all their health needs are met, regardless of how or where they accessed the system ${ }^{19}$. Despite some advances, what was observed in the RHD III was that the pyramid model still predominated, where compulsory primary health care represents the point of entry to services.

We have three levels: primary care has dentists as well as in the BHU [basic health unit]; the FHUs have specialized care and the DSCs have five specialties [endodontics, periodontics, oral lesion diagnosis, surgery and special patients] and the dental hospital, that's the third level. (MM8_Mango)

The point of entry is always the basic health unit; the service user enters via the unit, is assessed, or whatever needs to be done, and then the referral is made by the dentist within the unit. (MM7_Banana) 
The issue of integration of services is one of the most serious impediments to comprehensive health care. In a qualitative assessment study of comprehensiveness with respect to municipal health management, Kantorski et al..$^{42}$ noted that the various services did not communicate with each other and had their own distinct approaches. In addition, the axis of the organization was not focused on the health needs of the users. The present study found that integrated actions were restricted to the FHUs, under the principles of ascription and linkage. When actions of other levels of complexity were necessary, the system proved to be vulnerable and unable to satisfactorily address the needs of users. These results are similar to those of research by Oliveira and Saliba $^{22}$ who found that the oral health care in the Family Health Strategy in Campos dos Goytacazes eventually became the entry point to the system. However, it was not possible to organize oral health care because there were insufficient resources for more complex cases, i.e. the population was restricted to basic procedures and did not receive a full level of treatment. On the other hand, the results of a survey by Baldani et al. ${ }^{11}$, conducted in Paraná, were more promising; in only $9.5 \%$ of the municipal districts in the state were more complex cases unresolved or referred elsewhere.

In some municipalities in the RHD III, the system of reference and counter-reference works, while others have difficulty in operating this tool, both internally and for referrals to other cities with larger capacity.

Because the pent-up demand was very great at the start, it created some waiting lists. Also, there was no such service here in the city, so even the referrals that came in from the health units were missing details, they were incorrect about what had been done in the health unit, missing baseline data, such as patient-specific data. So, even with scheduling sometimes it gets complicated for us to find a patient because there are many patients on the waiting list. [...] Also, [on] our [part] improving counter-references to also give feedback to the dentist at the health unit for them to continue the service there. [...] The reference and counter-reference are divided and we report, in my case, I report everything that was done and what I also hope that the unit will carry out maintenance for me because it is actually much closer to the patient. [...] It's all done by an internal mailing service through a courier, between us and the unit. I think it should be computerized, they promise to computerize. Actu- ally, I think it would speed up more if it came via computer, but that would require having a computer in all the units, and we could do it all online [...]. (DS18_Mango)

The dental surgeons that work in emergency care units end up getting completely distanced from the oral health service network because they cannot even reference the users formally.

It is all done orally, by word of mouth; we don't have counter-referencing, nothing. (DS14_Banana)

There are established protocols regarding the scope of procedures for each level of care, which are still appropriated by some professionals.

There are certain rules laid down by the coordinator [municipal coordinator of oral health], which we must initially submit to the DSCs, for the experts here. When the service is not offered, the coordinator will try to make a referral to the Araraquara School of Dentistry, for example, or another service which can attend patients. There is a specific guideline; the patient is examined, if we do root canal treatment the treatment is urgent and emergency, we remove their pain and refer them to the specialist DSC. The guide is given to the patient and they come here and are scheduled for treatment. [After completing treatment in the DSC, the patient receives the guide for] counter-referral and take it to the Basic Unit [Health]. (FG4_Orange)

Analysing the process of referral and counter-referral in the municipalities that were visited, it is clear that this process is limited to the bureaucratic issue, in which each level of care 'pushes' the user to the services at another level. Given this framework, it is necessary to build a mechanism that actually constitutes shared care.

In the case study under consideration, the specialties of prosthodontics, periodontics and endodontics were those with the highest pentup demand; the latter has waiting lists that can exceed two years, which compromises the continuity of care at the secondary and tertiary levels and leaves users in a situation of greater vulnerability and facing future treatment involving mutilation. Scheduling has improved access to oral health services after it was included in the Family Health Strategy. However, much of the time such access is restricted to the primary care level, without proper attention to the secondary and tertiary levels ${ }^{28,36}$ This is often due to insufficient specialized services, which ultimately generates excessive demand ${ }^{10}$. Thus, comprehensive care provided to an enrolled population ceases to be 
administered by dental surgeons and families fail to have their needs and expectations met ${ }^{24}$.

\section{Intersectorality}

Intersectorality has been historically marked by partnerships between health and education departments; a partnership that has not always been amicable. The proposed strengthening of primary health care set out in the Family Health Strategy considers other areas/sectors of civil society to be desirable for the development of actions that expand the concept of the health-disease-care process, such as workplaces, commerce, the media, industry, non-governmental organizations and other institutions ${ }^{43,44}$.

I programmed a lot of things; everything was designed to address dental issues: for example, mathematics would be used to calculate how much tooth decay there is in Brazil,. We did a lot of things. But although the professors were enthusiastic, afterwards no one wanted to do anything, so I said: "I can't do this alone; to do it properly I would need your help". So I did some work there with some students and then it finished. (DS16_Banana)

There is very strong support from the community through the support of [the] Rotary [Club], and that school was a very structured school in terms of helping meet the region's needs. At that time there was a director who was an example, they did a great job with the help of SENAC, the schools, who went there to cut hair, to teach things to families. This started before the Family Health Strategy began, it started working there in that school with that structure, the more educational part, more towards education than health, and we were welcomed and we supported it. (FG3_Mango)

A study by Mattos et al. ${ }^{28}$ regarding the development of intersectoral action, which included the participation of 57 dental surgeons and managers, found that $75.44 \%$ of the participants reported performing intersectoral actions aimed at integrating oral health with other health services. Information and prevention regarding oral health in the community or schools were among the most important activities that were considered in that study.

\section{Hosting, linkage and accountability}

The concept of 'hosting' argues that health services should provide an answer for service users, whether clinical or not, in order to contribute to increased levels of resolution of problems. The linkage is constituted in the accountability of health services regarding the care of patients, and should be the result of reception ${ }^{19}$.

We have a big problem related to pent-up demand. We tried to solve this with reception, carrying it out in the units with risk rating. (MM9 Mango)

It is usually a case involving pain, drainage of an abscess, or an opening [coronary]. If the person has tooth decay we do a provisional restoration and the person ends up waiting to enter treatment, sometimes urgently. What we refer to as reception ends up being the point of entry to the program, sometimes it happens like that. (FG1_Banana)

Research by Santos et al..$^{45}$, carried out in Alagoinhas (BA) with professionals and service users of the Family Health Strategy, identified lines of tension associated with reception. In terms of individual care, basically three standards were established. Firstly, professional, with all technological apparatus available and appropriate related technology, but limited technical capacity, which compromised the quality of the procedures that were performed. Secondly, professional, with good technical ability and available technological apparatus, but restricted with respect to reception; and thirdly, creative situations were observed in the midst of procedures, i.e. professionals with limited capacity for resolution, but who sought, with the tools available to them, to overcome the difficulties and to develop processes for user-centred care.

The oral health professionals who participated in the present study observed little accountability of the part of service users for the care of their own health. While some professionals considered it almost impossible to act within this context and tended to blame individuals, others sought to develop tools to develop autonomy.

We work with a public that does not care [...], perfect hygiene. If you do not force them to brush their teeth or you don't teach them to use a prosthesis; there is no point in putting in a prosthesis, in six months they will lose it [...], because this is a very serious problem, it is a class that only goes to the dentist when they are in pain. (DS11_Orange)

To enable service users to make sense of the information that we pass onto them, so that they might change their daily habits, and that they can see that what we're telling them is interesting and that they can do their part at home, which will support us in our efforts to achieve the expected results. (DS23_Mango)

Evaluations of service user accountability from the perspective of oral health professionals should be analyzed with caution because 
there is a perceived tendency to blame patients themselves for their health problems. Because oral health professionals often have a limited and uncritical view of the social and economic conditions that influence the health of the population, they ultimately do not realize the complexity of social determinants and are doomed to fail because they disregard factors such as malnutrition, the cost of food, poor access to health services in general, as well as the fact that health services practice curative-mutilating dentistry. Without access to services, and facing so many other needs, the large majority of the population is not able to place great value on dental and soft tissue problems ${ }^{41}$.

\section{Humanization}

Humanization is one of the principles of a comprehensive approach to health care and it advocates an expanded vision of human beings, which is built and rebuilt, taking into consideration biological, subjective and social aspects ${ }^{19}$. This implies accountability on the part of services and health workers to collaboratively build, with the input of service users, wide-ranging care plans that are focused not only on consultations and appointments, but also on the expectation that the care process will produce knowledge, accountability and autonomy in each service user $^{43}$. In practice, what was observed in RHD III is that the principles and guidelines of the Family Health Strategy have contributed to the integration of the aforementioned aspects in terms of oral health care.

We have to see the person and their mouth as a whole, [...] total care. We worry about the well-being of the patients. [...] We do restorations, extractions, canal treatment and then we refer them on to see if they will have a prosthesis fitted. We refer them on so that they can smile, for their well-being. (OHA3_Açaí)

It's not enough just to see that context in isolation - that individual who comes here with a simple tooth problem, [...] You have to understand that they live in a place where they are influenced by their environment, there is a whole context that has an influence, and that has an effect on any complications that are reported to us. (DS23_Mango)

\section{Health surveillance}

The concept of health surveillance requires a paradigm shift in attitudes because it marks the transition of services that work on demand to services that actively pursue and constantly monitor service users ${ }^{43}$. The inclusion of oral health teams in the Family Health Strategy has been hailed as a potential break with oral health care models that are exclusive, curative, technical and biological, towards a health surveillance model that is based on a comprehensive approach that actively seeks out families ${ }^{23}$. Santos et al..$^{45}$ suggest that in order to solve the problem of pent-up demand it is necessary to organize spaces for negotiation in order to develop criteria for treatment in FHUs, home visits, and to carry out collective activities of promotion and prevention.

We also do visits to check the needs of the population. [...] We go out into the street. If the heath officer comes to us with a problem and says, "There is a case in such-and-such street, can you go and have a look?" [...] I program it into my diary and we go to the patient's house, the dentist and I, both of us. The majority are bedridden people, the elderly, someone with a mouth ulcer or an oral lesion that the family is in doubt about and the patient can't come to us. So, we go to their home. (OHA8_Jambo)

The registration of people in the community, as well as home visits, should be opportunities for the strengthening of relationships between professionals and also between professionals and service users. Visiting people in their own social and family context enables health workers to strengthen links with patients and contributes to the accessibility of services. It also makes it possible to solve problems that cause pain for patients who are unable to attend health units ${ }^{34}$.

I have a patient who is able to come here to the health unit [...] He has a complicated cognitive impairment [...] and an extremely complicated relationship with his family. In order to make contact with him I could simply make an appointment for him here in the health unit and ask him to come here. I had to go to his house to check out his home environment and then I realized that I was more than a dentist, I could be a friend of the family. [...] And today he comes, he is treated here. [...] I identified that he needs an occupational therapist, a psychologist and a speech therapist, something I would not have noticed otherwise. So, he had these needs, which I was able to verify by seeing him at home, which was the reason why he didn't want to come to the unit. (DS23_Mango)

\section{Final considerations}

Almost 10 years after the launch of the PNSB, municipalities in the RHD III still tend to main- 
tain a health care model that is focused on disease. A positive point to mention is the increase that has occurred in solving oral health cases at the primary health care level. Aspects of care that are present in the PNSB are consistent with the work done by the oral health teams working in family health units, where there is more evidence of a comprehensive approach, including the following aspects; interdisciplinarity; intersectorality; reception, linkage and accountability; the humanization of care; and working from a perspective of health surveillance.

Oral health professionals are also developing preventive intersectoral actions, which have been limited to lectures and topical fluoride applications in the community or in schools. There is also the prioritization of mothers/children and school children, a remnant of the incremental model of oral health care that prevailed in the period 1950-80.

A positive aspect of the PNSB is that it has afforded access to oral health care for many citizens. The strengthening and expansion of oral health practices in primary health care has increased demand for specialized treatment and the dental speciality centers are unable to satisfactorily meet that demand.

Another aspect is that the municipalities that presented the best contexts for implementing the PNSB participated in this study, which suggests that there may be similar or even worse situations regarding oral health care in other municipalities.

Thinking about changes in oral health care that can produce curative actions effectively in terms of results related to healing, promotion and protection is a critical issue that needs to be resolved by all health managers and health workers. Consolidation of the proposed changes will only occur through a reinterpretation of the work process in health and vocational training.

The results of this study were presented to the collegiate of the respective municipal oral health coordinators to support decision making by managers and it seems to have motivated a positive reflection and discussion of the results. 


\section{Collaborations}

AG Aquilante wrote this article, which was based on her doctoral thesis in the postgraduate program in public health at UNIFESP. GGA Silva participated in all the phases of the work, guiding the production and revising the article.

\section{Acknowledgements}

The authors would like to thank DECIT (the Department of Science and Technology) and the Ministry of Health, which through the $\mathrm{CNPq}$ (National Council for Scientific and Technological Development) provided the financial support for this study.

\section{References}

1. Pereira DQ, Pereira JCM, Assis MMA. A prática odontológica em Unidades Básicas de Saúde em Feira de Santana (BA) no processo de municipalização da saúde: individual, curativa, autônoma e tecnicista. Cien Saude Colet 2003; 8(2):599-609.

2. Costa JFR, Chagas LD, Silvestre RM, organizadores. A política nacional de saúde bucal do Brasil: registro de uma conquista histórica. Brasília: Organização Pan-Americana da Saúde (OPAS); 2006.

3. Narvai PC. Saúde bucal coletiva: caminhos da odontologia sanitária à bucalidade. Rev Saude Publica 2006; 40(N. Esp.):141-147.

4. Nickel DA, Lima FG, Silva BB. Modelos assistenciais em saúde bucal no Brasil. Cad Saude Publica 2008; 24(2):241-246.

5. Silveira Filho AD. A saúde bucal nas esferas de gestão do Sistema Único de Saúde (SUS). In: Botazzo C, Oliveira MA, organizadores. Atenção básica no Sistema Único de Saúde: abordagem interdisciplinar para os serviços de saúde bucal. São Paulo: Páginas \& Letras Editora e Gráfica; 2008. p. 31-49.

6. Ferreira EB, Abreu TQ, Oliveira AEF. Modelos assistenciais em saúde bucal no Brasil: revisão de literatura. Rev. Pesq. Saúde 2011; 12(3):37-42.

7. Pucca Junior GA. A política nacional de saúde bucal como demanda social. Cien Saude Colet 2006; 11(1):243-246.

8. Emmi DT, Barroso RFF. Avaliação das ações de saúde bucal no Programa Saúde da Família no distrito de Mosqueiro, Pará. Cien Saude Colet 2008; 13(1):35-41.

9. Manfredini MA. Saúde bucal no Brasil em 2008 e nos 20 anos de Sistema Único de Saúde. In: Brasil. Ministério da Saúde (MS). Secretaria de Vigilância em Saúde. Departamento de Análise de Situação de Saúde. Saúde Brasil 2008: 20 anos de Sistema Único de Saúde (SUS) no Brasil. Brasília: MS; 2009. p. 155-174.

10. Farias M-AV, Moura ERF. Saúde Bucal no Contexto do Programa Saúde da Família do Município de Iracema, no Ceará. Rev. odontol. UNESP 2003; 32(2):131-137.

11. Baldani MH, Fadel CB, Passamai T, Queiroz MGS. A inclusão da odontologia no Programa Saúde da Família no Estado do Paraná, Brasil. Cad Saude Publica 2005; 21(4):1026-1035.

12. Pereira CRS, Patrício AAR, Araújo FAC, Lucena EES, Lima KC, Roncalli AG. Impacto da Estratégia Saúde da Família com equipe de saúde bucal sobre a utilização de serviços odontológicos. Cad Saude Publica 2009; 25(5):985-996.

13. Figueiredo N, Goes PSA. Construção da atenção secundária em saúde bucal: um estudo sobre os Centros de Especialidades Odontológicas em Pernambuco, Brasil. Cad Saude Publica 2009; 25(2):259-267.

14. Goes PSA, Figueiredo N, Neves JC, Silveira FMM, Costa JFR, Pucca Júnior GA, Rosales MS. Avaliação da atenção secundária em saúde bucal: uma investigação nos centros de especialidades do Brasil. Cad Saude Publica 2012; 28(Supl.):S81-S89.

15. Minayo MCS, Assis SG, Souza ER, organizadores. Avaliação por triangulação de métodos: abordagem de programas sociais. Rio de Janeiro: Fiocruz; 2005. 
16. Souza ER, Minayo MCS, Deslandes SF, Veiga JPC. Construção dos instrumentos qualitativos e quantitativos. In: Minayo MCS, Assis SG, Souza ER, organizadores. Avaliação por triangulação de métodos: abordagem de programas sociais. Rio de Janeiro: Fiocruz; 2005. p. 133-156.

17. Minayo MCS. Construção dos instrumentos e exploração de campo. In: Minayo MCS. O desafio do conhecimento: pesquisa qualitativa em saúde. São Paulo: Hucitec; 2006. p. 189-199.

18. Gomes R, Souza ER, Minayo MCS, Malaquias JV, Silva CFR. Organização, processamento, análise e interpretação de dados: o desafio da triangulação. In: Minayo MCS, Assis SG, Souza ER, organizadores. Avaliação por triangulação de métodos: abordagem de programas sociais. Rio de Janeiro: Fiocruz; 2005. p. 185-221.

19. Mattos RA. Os sentidos da integralidade: algumas reflexões acerca de valores que merecem ser defendidos. In: Pinheiro R, Mattos RA, organizadores. Os sentidos da integralidade na atenção e no cuidado à saúde. Rio de Janeiro: UERJ, Abrasco; 2001. p. 39-64.

20. Andrade KLC, Ferreira EF. Avaliação da inserção da odontologia no Programa Saúde da Família de Pompéu (MG): a satisfação do usuário. Cien Saude Colet 2006; 11(1):123-130.

21. Cericato GO, Garbin D, Fernandes APS. A inserção do cirurgião-dentista no PSF: uma revisão crítica sobre as ações e os métodos de avaliação das Equipes de Saúde Bucal. RFO UPF 2007; 12(3):18-23.

22. Oliveira J-LC, Saliba NA. Atenção odontológica no Programa de Saúde da Família de Campos dos Goytacazes. Cien Saude Colet 2005; 10(Supl.):297-302.

23. Souza TMS, Roncalli AG. Saúde bucal no Programa Saúde da Família: uma avaliação do modelo assistencial. Cad Saude Publica 2007; 23(11):2727-2739.

24. Rocha ECA, Araújo MAD. Condições de trabalho das equipes de saúde bucal no Programa Saúde da Família: o caso do Distrito Sanitário Norte em Natal, RN. Rev. adm. pública 2009; 43(2):481-517.

25. Pereira CRS, Roncalli AG, Cangussu MCT, Noro LRA, Patrício AAR, Lima KC. Impacto da Estratégia Saúde da Família sobre indicadores de saúde bucal: análise em municípios do Nordeste brasileiro com mais de $100 \mathrm{mil}$ habitantes. Cad Saude Publica 2012; 28(3):449-462.

26. Aerts D, Abegg C, Cesa K. O papel do cirurgião-dentista no Sistema Único de Saúde. Cien Saude Colet 2004; 9(1):131-138.

27. Santos AM, Assis MMA. Da fragmentação à integralidade: construindo e (des)construindo a prática de saúde bucal no Programa de Saúde da Família (PSF) de Alagoinhas, BA. Cien Saude Colet 2006; 11(1):53-61.

28. Mattos GCM, Ferreira EF, Leite ICG, Greco RM. A inclusão da Equipe de Saúde Bucal na Estratégia Saúde da Família: entraves, avanços e desafios. Cien Saude Colet 2014; 19(2):373-382.

29. Ayres JRCM. O cuidado, os modos de ser (do) humano e as práticas de saúde. Saúde e Sociedade 2004; 13(3):16-29.

30. Gomes R, Deslandes SF. Interdisciplinaridade na saúde pública: um campo em construção. Rev. latinoam. enferm 1994; 2(2):103-114.
31. Raynaut C. Interdisciplinaridade e promoção da saúde: o papel da antropologia. Algumas idéias simples a partir de experiências africanas e brasileiras. Rev. bras. epidemiol 2002; 5(Supl.1):43-55.

32. Cordón J. A construção de uma agenda para a saúde bucal coletiva. Cad Saude Publica 1997; 13(3):557-563.

33. Silva LS, Santana KR, Pinheiro HHC, Nascimento LS. Indicadores de atenção básica e especializada em saúde bucal nos municípios do Estado do Pará, Brasil: estudo ecológico, 2001-2010. Epidemiol. Serv. Saúde 2013; 22(2):325-334.

34. Costa RM, Medeiros Junior A, Costa ICC, Pinheiro IVA. O trabalho em equipe desenvolvido pelo cirurgião-dentista na Estratégia Saúde da Família: expectativas, desafios e precariedades. Rev. Bras. Med. Fam. Comunidade 2012; 7(24):147-163.

35. Araújo LC. Programa Saúde da Família pelo olhar do cirurgião-dentista [dissertação]. Natal: Universidade Federal do Rio Grande do Norte; 2005.

36. Vilarinho SMM, Mendes RF, Prado Júnior RR. Perfil dos cirurgiões-dentistas integrantes do Programa Saúde da Família em Teresina (PI). Rev. odonto ciênc 2007; 22(55):48-54.

37. Araújo MBS, Rocha PM. Trabalho em equipe: um desafio para a consolidação da estratégia de saúde da família. Cien Saude Colet 2007; 12(2):455-464.

38. Mazon L, Trevizan MA. Fecundando o processo da interdisciplinaridade na iniciação científica. Rev. latinoam. Enferm 2001; 9(4):83-87.

39. Saupe R, Cutolo LRA, Wendhausen ALP, Benito GAV. Competência dos profissionais da saúde para o trabalho interdisciplinar. Interface (Botucatu) 2005; 9(18): 521-536.

40. Vilela EM, Mendes IJM. Interdisciplinaridade e saúde: estudo bibliográfico. Rev. latinoam. Enferm 2003; 11(4):525-531.

41. Pauleto ARC, Pereira MLT, Cyrino EG. Saúde bucal: uma revisão crítica sobre programações educativas para escolares. Cien Saude Colet 2004; 9(1):121-130.

42. Kantorski LP, Jardim VMR, Coimbra VCC, Oliveira MM, Heck RM. A integralidade da atenção à saúde na perspectiva da gestão do município. Texto contexto enferm 2006; 15(3):434-441.

43. Brasil. Ministério da Saúde (MS). Secretaria de Atenção à Saúde. Departamento de Atenção Básica. Coordenação Nacional de Saúde Bucal. Diretrizes da Política Nacional de Saúde Bucal. Brasília: MS; 2004.

44. Colussi CF, Calvo MCM. Modelo de avaliação da saúde bucal na atenção básica. Cad Saude Publica 2011; 27(9):1731-1745.

45. Santos AM, Assis MMA, Rodrigues AAAO, Nascimento MAA, Jorge MSB. Linhas de tensões no processo de acolhimento das equipes de saúde bucal do Programa Saúde da Família: o caso de Alagoinhas, Bahia, Brasil. Cad Saude Publica 2007; 23(1):75-85.

Article submitted 29/10/2013

Approved 16/03/2014

Final version submitted 21/03/2014 